\title{
Peran Kebijakan Moneter Terhadap Kemampuan Perbankan Dalam Penyaluran Pembiayaan
}

\author{
Moch Anshori ${ }^{1 *}$, M. Alif Shofiyuddin ${ }^{2)}$ \\ ${ }^{1,2}$ Pascasarjana Ekonomi syariah, UIN Malang \\ *Email korespondensi: penulis ansormilan@gmail.com
}

\begin{abstract}
The purpose of this study is to see the response of Islamic banking in Indonesia from monetary policy. This research uses quantitative methods. The data used are the 2017-2019 financial statements. The results of this study indicate that the bank is not in a financial condition. This, coupled with liquidity in banks, monetary and monetary effects will not affect financing. As for capital, monetary policy changes will affect finances.
\end{abstract}

Abstract

Keywords : monetary policy, capital, liquidity, size

Saran sitasi: Anshori, M., \& Shofiyuddin, M. A. (2021). Peran Kebijakan Moneter Terhadap Kemampuan Perbankan Dalam Penyaluran Pembiayaan. Jurnal Ilmiah Ekonomi Islam, 7(01), 51-54. doi:http://dx.doi.org/10.29040/jiei.v7i1.1758

DOI: http://dx.doi.org/10.29040/jiei.v7i1.1758

\section{PENDAHULUAN}

Negara indonesia merupakan negara berkembang. Dalam hal ekonomi, sumber utama permodalan untuk kegiatan sektor ekonomi masih dari aliran kredit dan utang luar negegri. Hal ini hampir terjadi di seluruh Negara berkermbang. Di kutip dari CNNindonesia.com bahwa sumber pendanaan terbesar bagi perekonomian Indonesia berasal dari aliran kredit bank umum dan Utang Luar Negeri (ULN).

Berdasarkan data BI, sumbangan dari kredit bank dan ULN mencapai Rp7.353 triliun atau 80,86 persen dari total pembiayaan yang mengalir di perekonomian nasional yang senilai Rp9.093 triliun. Rinciannya, kontribusi aliran kredit bank umum mencapai Rp5.220 triliun dan ULN Rp2.133 triliun.

Hal tersebut membuktikan bahwa ketergantungan sumber dana ekonomi di Indonesia masih bergantung pada kredit perbankan umum. Hal ini dapat dijadikan evaluasi bagi pembuat kebijakan moneter supaya bisa menjaga kestabilan sistem keuangan tersebut. Apabila terjadi keteledoran sistem keuangan, maka tidak mungkin akan berimbas pada perekonomian yang ada di Indonesia sendiri, sebab sumber utama permodalan dalam sector ekonomi berasal dari aliran kredit.
Sistem perbankan Indonesia sudah pernah diuji pada tahun krisis moneter 1997, dimana banyak perbankan yang bangkrut dan bermasalah. Namun, krisis moneter memberikan pelajaran penting dalam perbaikan kebijakan keuangan dan sistem perbankan juga. Dalam memainkan peran penting dalam pertumbuhan ekonomi,maka perbankan secara umum melakukan merger dan akuisisi.

Dalam upaya merger dan akuisisi diharapkan bisa berdaya saing lagi. Namun, terdapat satu perbankan yang masih berdiri dan bisa menghadapi krisis moneter yaitu bank Muamalat. Salah satu bank syariah di Indonesia pada masa itu. Hal ini membuat system perbankan islam menjadi system yang unik bagiperusahaan perbankan di Indonesia.

Setelah terjadinya krisis pertumbuhan perbankan syariah cukup signifikan, dimana Jumlah lembaga perbankan syariah semakin meningkat dari waktu ke waktu. Skenario ini mendorong terjadinya persaingan dalam kegiatan penyaluran kredit yang melibatkan lembaga perbankan syariah dan konvensional. Dalam situasi ini, memberikan tantangan kepada para pembuat kebijakan untuk menjalankan alat sasaran kebijakan moneter yang berbasis sistem bebas bunga.

Penelitian empiris telah memberi arti penting pada saluran pinjaman bank. Beberapa penelitian 
empiris menggunakan data agregat dan lainnya menggunakan data tingkat perusahaan. Kajian tentang jalur peminjaman bank dibagi menjadi dua kelompok, yaitu kajian tingkat makro dan kajian tingkat perusahaan. Hal ini membuktikan bahwa saluran pinjaman banksangat penting, berikut terdapat penelitian empiri yang dilakukan di beberapa Negara:

Misalnya, di Amerika Serikat, menurut Bernanke dan Blinder (1992), Kashyap dkk. (1993), (Kishan \& Opiela, 2000) dan juga Kashyap dan Stein (2000) .Mengikuti efisiensi saluran ini, penelitian yang lain seperti Di negara-negara Eropa, Kashyap dan Stein (1997) Di Inggris Raya (UK), Italia dan Portugal. Kakes dan Sturm (2002) di Jerman, hal tersebut sampai di benua asia seperti, Hosono (2006) di Jepang dan Gunji dan Yuan (2010) Di Tiongkok.

Dalam Penelitian (Karim et al., 2018) memanfaatkan data cross-sectional yang melibatkan variabel karakteristik bank tertentu seperti ukuran, permodalan dan likuiditas untuk membuktikan respon pemberian kredit bank terhadap shock kebijakan moneter. Variabel spesifik ini penting dan perlu diperhatikan dalam penelitian, karena tingkat respon antar bank berbeda-beda.

Hipotesis yang diuji dalam saluran ini mengasumsikan bahwa ukuran bank yang kecil, likuiditas yang lebih sedikit, dan kurangnya modal menunjukkan tingkat perubahan yang tinggi setiap kali kebijakan yang ketat dan ketat diterapkan ( Kashyap dan Stein, 1995 , 2000 ; Kishan dan Opiela, 2000 ).

Penelitian yang sama dilakukan di Indonesia antara lain (Wibowo \& Mubarok, 2018), (Mayo et al., 2014; Yeniwati dan \& Riani, 2010). Dari penelitian diatas temuan nya masih bersifat umum, sebab lembaga perbankan tidak dikategorikan menjadi perbankan syariah dan perbankan konvensional. Perbedaan ini harus diprioritaskan, karena prinsip yang mendasari kedua sistem tersebut berbeda.

Lebih lanjut, kajian ini akan menganalisis secara rinci efektivitas perangkat sasaran kebijakan moneter sebagai transmisi kebijakan moneter bagi BI. Dalam penelitian ini juga akan dianalisis tiga karakteristik spesifik bank. Selain itu, untuk menganalisis perbedaan respon penawaran pembiayaan bank.

Maka dari itu, dalam penelitian ini akan mengkaji respon penawaran kredit pada sektor ekonomi yang dikenal dengan pembiayaan oleh lembaga perbankan syariah dalam menghadapi perubahan kebijakan moneter.

\section{METODE PENELITIAN}

Populasi dalam penelitian ini ialah bank umum Syariah di Indonesia tahun 2017-2019. Jumlah populasi bank umum syariah di Indonesia ada sebanyak 12 bank. Pengambilan sampel dalam penelitian ini dengan menggunakan teknik purposive, Dalam menentukan jumlah sampel terdapat beberapa kriteria yang digunakan, yaitu: Pertama, Bank tersebut mempublikasikan laporan keuangan yang lengkap selama periode pengamatan (tahun 2017- 2019). Bank harus memiliki minimal 3 tahun data laporan keuangan yang dipublikasikan.

Pendekatan dalam penelitian ini menggunakan pendekatan yang dikenalkan oleh Bernanke dan Blinder (1988) dalam (Satria \& M. Juhro, 2011) dan Kashyap dan Stein (1995,2000) dalam(Kishan \& Opiela, 2000).Pendekatan ini banyak digunakan dalam menganalisis adanya jalur kredit lebih khusus bank lending channel dan menganalisis respons bank terhadap peubahan biaya pinjaman. Persaman dalam penelitian ini yaitu:

$$
\begin{aligned}
\left(\Delta \log T F_{i, t}\right)= & \alpha_{i}+\beta_{1} \Delta \sum_{j=0}^{1}\left(\log Y_{t}\right)+\beta_{3} \Delta S B I S_{t} \\
& +\beta_{4} \Delta \sum_{j=0}^{1} X_{i, t-1} \\
& +\beta_{5} \Delta \sum_{j=0}^{1} \Delta S B I S * X_{i, t-1}+\epsilon_{i, t}
\end{aligned}
$$

Keterangan

$\Delta \log T F_{i, t}=$ penyaluran pembiayaan

$\mathrm{Y} \quad=\mathrm{PDB}$

SBIS $\quad=$ sertifikat bank Indonesia syariah

$\mathrm{X}=$ karakteristik khusus bank (Liquiditas, modal, size)

Dalam jurnal ini menggunakan pendekatan data panel. Dalam pendekatan data panel data panel sebagai data yang memiliki dimensi cross-sectional dan time-series. Selanjutnya, dilakukan pengujian model. Yaitu menganalisis model efek tetap dan efek acak. Oleh karena itu, Hausman tes digunakan untuk menentukan apakah ada korelasi antara variabel penjelas dan istilah kesalahan. Jika ada hubungan seperti itu, maka model efek tetap dikatakan sesuai.

\section{HASIL DAN PEMBAHASAN}

3.1. Hasil penelitian

Pada penentuan model dalam regresi data panel, terdapat penentuang model apa yang digunakan. Maka dari itu dalam penelitian menggunakan model random 


\section{Jurnal Ilmiah Ekonomi Islam, 7(01), 2021, 53}

effect, dimana penentuan tersebut mengacu pada uji hausmant dimana pengaruh individual tidak berkorelasi dengan variabel penjelas, hasilnya sebagai berikut:

\begin{tabular}{lrrr}
\hline \hline & Chi-Sq. & Chi-Sq. & \\
Test Summary & Statistic & d.f. & Prob. \\
\hline \hline $\begin{array}{l}\text { Cross-section } \\
\text { random }\end{array}$ & 2.000368 & 3 & 0.5723 \\
\hline \hline
\end{tabular}

Dari tabel diatas menunjukkan nilai probabilitas pada uji hausman sebesar 0.5723 , yang artinya nilai probabilitas lebih dari 0,05 maka dari itu, metode yang baik yaitu model random effek. Berikut hasil dari random effek:

\begin{tabular}{ccccc}
\hline \hline Variable & Coefficient & Std. Error & t-Statistic & Prob. \\
\hline \hline GDP & -0.037767 & 0.068371 & -0.552378 & 0.5836 \\
SBIS & 0.007524 & 0.009181 & 0.819509 & 0.4171 \\
CAP & 0.158983 & 0.089228 & 1.781756 & 0.0820 \\
LIQ & 0.004151 & 0.003984 & 1.041841 & 0.3034 \\
SIZE & 0.010105 & 0.027162 & 0.372024 & 0.7117 \\
C & 0.106436 & 0.810066 & 0.131392 & 0.8961 \\
\hline \hline
\end{tabular}

a. Berdasarkan table diatas, bahwa variabel GDP terhadap penyaluran Pembiayaan didapatkan nilai coefisien negatif sebesar 0.037767 dan tidak signifikan dengan demikian tidak ada pengaruh dari GDP terhadap penyaluran pembiayaan.

b. Berdasarkan table diatas, bahwa variable SBIS terhadap penyaluran Pembiayaan didapatkan nilai coefisien positif sebesar 0.0077524 dan tidak signifikan dengan demikian tidak ada pengaruh dari likuiditas bank terhadap penyaluran pembiayaan.

c. Berdasarkan hasil uji variabel ukuran bank terhadap penyaluran Pembiayaan diperoleh nilai koefisien positif sebesar 0.010105 dan tidak signifikan. dengan demikian tidak terdapat pengaruh dari ukuran bank terhadap penyaluran pembiayaan.

d. Berdasarkan table diatas, bahwa variable likuiditas terhadap penyaluran Pembiayaan didapatkan nilai coefisien positif sebesar 0.004151 dan tidak signifikan dengan demikian tidak ada pengaruh dari likuiditas bank terhadap penyaluran pembiayaan..

e. Berdasarkan hasil uji variabel capital bank terhadap penyaluran Pembiayaan diperoleh nilai koefisien positif sebesar 0.158983 dan signifikan dengan demikian terdapat pengaruh positif dari capital bank terhadap penyaluran pembiayaan.
Dengan kata lain apabila Dengan menganggap variabel lain konstan, setiap penambahan satu satuan pada capital bank maka akan menaikkan penyaluran pembiayaan sebesar 0.158983 .

Selanjutnya melihat interaksi antara karakteristik bank dan suku bunga kebijakan moneter syariah hasilnya sebagai berikut

\begin{tabular}{ccccc}
\hline \hline Variable & Coefficient & Std. Error & t-Statistic & Prob. \\
\hline GDP & -0.035787 & 0.067460 & -0.530497 & 0.5986 \\
SBIS & -0.024711 & 0.104935 & -0.235489 & 0.8150 \\
CAP_SBIS & 0.028358 & 0.014843 & 1.910585 & 0.0629 \\
LIQ_SBIS & 0.000620 & 0.000567 & 1.093453 & 0.2804 \\
SIZE_SBIS & 0.000791 & 0.003447 & 0.229419 & 0.8197 \\
C & 0.450863 & 0.364564 & 1.236717 & 0.2231 \\
\hline \hline
\end{tabular}

Dari table diatas menunjukkan bahwa Dari segi interaksi antara karakteristik bank dan suku bunga kebijakan moneter syariah, Hipotesis dalam jalur kredit mengimplikasikan bahwa bank syariah dengan modal yang baik maka akan meningkatkan jumlah pembiayaan karena adanya guncangan dalam kebijakan keuangan.

Situasi ini Sesuai dengan literatur saluran pinjaman bank, bank-bank yang bermodal besar mampu menahan aktivitas pembiayaan mereka dari guncangan yang mempengaruhi ketersediaan keuangan eksternal. Sedangkan Bank-bank yang bermodal besar juga dapat mengembangkan pembiayaannya karena memiliki banyak cabang yang memungkinkan akumulasi simpanan yang besar.

Sedangkan,untuk interaksi lain yaitu likuiditas dilihat Dari segi interaksi antara karakteristik bank dan suku bunga kebijakan moneter syariah, Hipotesis dalam jalur kredit mengimplikasikan bahwa bank syariah dengan likuiditas yang kurang atau baik tidak akan mempengaruhi jumlah pembiayaan karena adanya guncangan dalam kebijakan keuangan. Sebab bank umum syariah diindonesia likuiditasnya masih tergolong kurang.

Lebih lanjut, untuk interaksi antara ukuran dilihat Dari segi interaksi antara karakteristik bank dan suku bunga kebijakan moneter syariah, Hipotesis dalam jalur kredit mengimplikasikan bahwa bank syariah dengan ukuran yang besar maupun kecil tidak akan mempengaruhi jumlah pembiayaan karena adanya guncangan dalam kebijakan keuangan. 


\section{KESIMPULAN}

Berdasarkan hasil penelitian maka dapat disimpulkan sebagai berikut :

a. Secara parsial dari kelima variabel yaitu GDP, SBIS, Capital, Liquiditas, dan ukuran, hanya Capital saja yang berpengaruh signifikan terhadap penyaluran pembiayaan.

b. Dilihat dari interaksi antara karakteristik bank dan suku bunga kebijakan moneter, dimana karakteristik bank dilihat dari, modal, ukuran dan liquiditas. Hanya bank syariah dengan modal yang baik maka akan meningkatkan jumlah pembiayaan karena adanya guncangan dalam kebijakan keuangan.

Berdasarkan hasil penelitian. Maka, peneliti memberikan saran untuk peneliti selanjutnya atau untuk pihak-pihak yang membutuhkan. Sebagai berikut:

a. Dalam penelitian ini terbatas dalam melihat karakteristik perbankan, yakni hanya 3 karakteristik. Sehingga kemungkinan terdapat perbedaan apabila menggunakan karakteristik perbankan yang lain.

\section{REFERENSI}

Karim, A., Higuchi, H., \& Nawata, E. (2018). Participatory Research Experience on the Introduction of Mungbean and Short Duration Aman Rice as Summer Crops in the Char Lands of Northern Bangladesh. Tropical Agriculture and Development, 62(1), 14-23.
Kishan, R. P., \& Opiela, T. P. (2000). Bank Size, Bank Capital, and the Bank Lending Channel. Journal of Money, Credit and Banking, 32(1), 121. https://doi.org/10.2307/2601095

Mayo, R., Maskie, G., \& Pratomo, D. S. (2014). Efektivitas Jalur Kredit dalam Mekanisme Transmisi Kebijakan Moneter di Indonesia. Jurnal Keuangan Dan Perbanakan, 18(1), 152160.

Satria, D., \& M. Juhro, S. (2011). Perilaku Risiko Dalam Mekanisme Transmisi Kebijakan Moneter Di Indonesia. Buletin Ekonomi Moneter Dan Perbankan, 13(3), 251-280. https://doi.org/10.21098/bemp.v13i3.262

Wibowo, M. G., \& Mubarok, A. (2018). Analisis Efektivitas Transmisi Moneter Ganda Terhadap Pertumbuhan Ekonomi Indonesia. Jurnal Ekonomi Pembangunan, 25(2), 127-139. https://doi.org/10.14203/jep.25.2.2017.127-139

Yeniwati dan, \& Riani, N. Z. (2010). Jalur Kredit Perbankan dalam Mekanisme Transmisi Kebijakan Moneter di Indonesia. Jurnal Tingkap, 6(2), 101-114. 